\title{
Design and evaluation of a sensor network for medical monitoring in areas of difficult access
}

\section{Diseño y evaluación de una red de sensores para monitoreo medico en áreas de difícil acceso}

\section{Projeto e avaliação de uma rede de sensores para monitoramento médico em áreas de difícil acesso}

\author{
Yarisol Castillo Quiel ${ }^{1}$ \\ Amilkar Saavedra² \\ Vladimir Villarreal ${ }^{3}$
}

\author{
Received: May $5^{\text {th }}, 2020$ \\ Accepted: July $28^{\text {th }}, 2020$ \\ Available: September $20^{\text {th }}, 2020$
}

How to cite this article:

Y. Castillo Quiel, A. Saavedra, V. Villarreal, "Design And Evaluation of A Sensor Network For Medical Monitoring In Areas of Difficult Access," Revista Ingeniería

Solidaria, vol. 16, no. 3, 2020.

doi: https://doi.org/10.16925/2357-6014.2020.03.11

Artículo de investigación. https://doi.org/10.16925/2357-6014.2020.03.11

1 Universidad Tecnológica de Panamá, Computer Systems Engineering Faculty, Professor.

ORCID: https://orcid.org/0000-0002-3527-0719

E-mail: yarisol.castillo@utp.ac.pa

https://scienti.minciencias.gov.co/cvlac/visualizador/generarCurriculoCv.do?cod_rh= 0001811639

2 Universidad Tecnológica de Panamá, Member of the Research Group on Emerging Computer Technologies.

ORCID: https://orcid.org/0000-0002-8158-2107

E-mail: amilkar.saavedra@utp.ac.pa

https://scienti.minciencias.gov.co/cvlac/visualizador/generarCurriculoCv.do?cod_rh= 0001810670

3 Universidad Tecnológica de Panamá, Computer Systems Engineering Faculty, Professor. Universidad Tecnológica de Panamá, Coordinator of the Research Group on Emerging Computer Technologies.

ORCID: https://orcid.org/0000-0003-4678-5977

E-mail: vladimir.villarreal@utp.ac.pa

https://scienti.minciencias.gov.co/cvlac/visualizador/generarCurriculoCv.do?cod_rh= 0001797404 


\begin{abstract}
Introduction: This article is the result of the research "Framework for the implementation of IPv6 using 6LoWPAN in sensor networks to facilitate the monitoring and control of people with dependency needs" developed at the Universidad Tecnológica de Panamá in the year 2019-2020.

Problem: The medical care of patients in rural areas of Panama is a priority, they need a constant follow-up and monitoring of their illness, there is no system that allows medical personnel to keep a continuous control.

Objective: The research proposes the development of a system with electronic devices using low power networks, which allows patients to send their clinical data to a central server, storing them and later a doctor can make an evaluation of the disease to keep a control, follow up and monitoring of the patients that reside in areas of difficult access.
\end{abstract}

Methodology: For the design and progressive development of the system, the use of the incremental methodology is proposed.

Results: Once developed both the hardware and the software, we tested the model in different scenarios recording measurements for pulse at different distances.

Conclusion: The implementation of a low-cost system offers the possibility to patients, who do not have access to regular health services, to have a better control and recommendations from the doctor.

Originality: Some similar systems have been developed, but not all of them contemplate security aspects for the handling of sensitive and delicate data.

Limitations: The maximum distance allowed is 60 meters at the time of testing the data.

Keywords: 6LoWPAN (IPv6 over Low power Wireless Personal Area Networks), ipv6 (Internet Protocol version 6), WSN (Wireless sensor networks), sensors.

\title{
Resumen
}

Introducción: El presente artículo es resultado de la investigación “Framework para la implementación de IPv6 utilizando 6LoWPAN en redes de sensores para facilitar el seguimiento y control de personas con necesidad de dependencia" desarrollada en la Universidad Tecnológica de Panamá en el año 2019-2020.

Problema: La atención médica de pacientes en áreas rurales de Panamá es prioritaria, necesitan un seguimiento y monitoreo constante de su enfermedad, no se cuenta con un sistema que permita al personal médico llevar un control de forma continua.

Objetivo: La investigación propone el desarrollo de un sistema con dispositivos electrónicos utilizando redes de baja potencia, que permita a los pacientes enviar sus datos clínicos a un servidor central, almacenándolos y posteriormente un médico pueda realizar una evaluación de la enfermedad para llevar un control, seguimiento y monitoreo de los pacientes que residen en áreas de difícil acceso.

Metodología: Para el diseño y desarrollo de manera progresiva del sistema se propone la utilización de la metodología incremental.

Resultados: Una vez desarrollados tanto el hardware, como el software pusimos a prueba el modelo en diferentes escenarios registrando mediciones para pulso a diferentes distancias.

Conclusión: La implementación de un sistema de bajo costo ofrece la posibilidad a pacientes, que no tienen acceso a servicios de salud regular, de llevar un mejor control y recomendaciones del médico.

Originalidad: Se han desarrollado algunos sistemas parecidos, pero no en todos se contemplan aspectos de seguridad para el manejo de datos sensitivos y delicados. 
Limitaciones: La distancia máxima permitida de 60 metros al momento de testear los datos.

Palabras clave: 6LoWPAN (IPv6 over Low power Wireless Personal Area Networks), ipv6 (Internet Protocol version 6), WSN (Wireless sensor networks), sensores.

\section{Resumo}

Introdução: Este artigo é o resultado da pesquisa "Framework para a implementação de IPv6 utilizando 6LoWPAN em redes de sensores para facilitar o monitoramento e controle de pessoas com necessidades de dependência" desenvolvida na Universidad Tecnológica de Panamá no ano 2019-2020.

Problema: 0 atendimento médico aos pacientes nas zonas rurais do Panamá é uma prioridade, eles precisam de um acompanhamento e monitoramento constantes de sua doença, não existe um sistema que permita ao pessoal médico manter um controle contínuo.

Objetivo: A pesquisa propõe o desenvolvimento de um sistema com dispositivos eletrônicos utilizando redes de baixa potência, que permite ao paciente enviar seus dados clínicos para um servidor central, armazenando-os e posteriormente um médico possa fazer uma avaliação da doença para manter um controle, acompanhar levantamento e acompanhamento dos pacientes que residem em áreas de difícil acesso.

Metodologia: Para o projeto e desenvolvimento progressivo do sistema, é proposta a utilização da metodologia incremental.

Resultados: Depois de desenvolver o hardware e o software, testamos o modelo em diferentes cenários, registrando medições de pulso em diferentes distâncias.

Conclusão: A implantação de um sistema de baixo custo oferece aos pacientes, que não têm acesso aos serviços regulares de saúde, a possibilidade de um melhor controle e recomendações do médico.

Originalidade: Alguns sistemas semelhantes foram desenvolvidos, mas nem todos contemplam aspectos de segurança para o manuseio de dados sensíveis e delicados.

Limitações: A distância máxima permitida é de 60 metros no momento do teste dos dados.

Palavras-chave: 6LoWPAN (IPv6 em redes de área pessoal sem fio de baixa potência), ipv6 (Internet Protocol versão 6), WSN (redes de sensores sem fio), sensores.

\section{INTRODUCTION}

The advance of science has developed new methodologies and technologies every day that bring countless inventions to the medical area, simplifying the manual processes, new discoveries benefit the whole society, and support tools to assist the health care staff. Medical technology plays an important role in health caring of patients and populations. The technological advances we have assisted in recent years have completely modified the scenario of clinical care, and the possibilities for public health intervention. However, the rapid process of technological innovation, requires the use of evaluation techniques to quickly and accurately analyze the potential impact of new technologies [1]. Institutions as government entities have promoted programs that allow patients to enjoy a comfort zone and make their lifestyle comfortable; 
however, there are currently certain gaps, specifically in the health area, where current technologies do not provide such comfort.

Over the years it has been seen that medical care in geographical areas of difficult access has always been a common problem in most third-world countries. Some countries have been supported by the World Health Organization (WHO) as is the case in Nigeria, where basic health care measures were implemented. This fragile situation in areas of difficult access, means they do not have medical supplies, and medical staff is scarce, besides the lack of drinking water [2]. It should be emphasized that countries in the Americas region suffers most problems in the sense of equity in health services, being the economy one of the key factors[3].

In recent years medical care in areas with difficult access in Panama has been seen as a priority, either because there are no roads, access only possible by water routes, or because it is very far from populated places, today the national government has improved somewhat this task with the regular cater of medical supplies and other laboratory services, as well as health inspections at various trading points [4]. However, for patients who need constant follow up and monitoring of their disease there is no system that allows medical staff to carry out a continuous control, and because such care becomes more effective in rural health centers with internet access, where technology performs better.

This system has electronic devices linked to a low power wireless network technology 6LoWPAN, (IPv6 over Low power Wireless Personal Area Networks) [5], using WSN (Wireless Sensors Networks)[6] to transmit data and coordinate the information emission between devices and its communication protocol 802.15.4 [7]. These WSNs are characterized by their nodes, which are conformed by microcontrollers with low processing capacity, they operate with batteries, at low transmission speeds, and are designed to be operational for long periods of time [8], thus allowing patients with no internet access to send their clinical data to a server where it is stored, and then the doctors can perform the respective and adequate assessment of the disease.

\subsection{Related works}

We will cover them briefly, demonstrating the most outstanding points that have served as support and reference to our project:

In the research [8], a monitoring system prototype was developed for older adult main vital signs control, this prototype allowed wireless data transmission from the patient to a data storage terminal where all the information is collected, the vital signs of the patient were seen in a local or remote terminal, through a computer or a 
mobile device, including the glucose value which is manually entered by the patient. The system uses pure open PHP (Hypertext Preprocessor) and Netbeans [9], it has poor measurement and validations in the testing phase.

The paper presented by the Corporación Universitaria de Huila [10], sets design parameters for a system of measurement of the body temperature for high fever episodes; and thus carry out preventive actions in case of possible febrile convulsions. This work analyzed the information and established guidelines for the system development; choosing the Arduino LilyPad platform as a collecting device and signal processor and then sending information to a mobile device. In our analysis, we determined: this work is not a WSN in its structure; also, we see it has the data gateway sequence, it goes from an Arduino $\rightarrow$ Bluetooth $\rightarrow$ Cellular $\rightarrow$ Database $\rightarrow$ Caregiver Interface.

The details of the study [11], describe a prototype developed in the University of Guayaquil, with the design of a wireless sensors network for hypertension monitoring with patients in gestation. The objective of this work was to monitor hypertension pregnant patients, storing the results in a database linked to a mobile application. Based on our analysis, this project does not implement a network with 6LoWPAN, or better said, it does not meet the characteristics of a WSN. In its implementation design, the sensor was connected directly to the Arduino, and then the data passes via Bluetooth to a mobile application (created with App inventor) and eventually sent to the server.

The project proposed by Yauri [12] shows the importance of the electronic components selection. This project is very complete in terms of the physical and electronic design of the WSN, the wireless network of sensors was developed for monitoring certain physiological variables in outpatients. However, there is a weakness detected in this system, since it was mostly focused on the use of pure electronics, the programming was left in the background. We did not find roles for patients and doctors, neither characteristics of security implementation.

In [13] we see the result of a research that developed a mobile application to the self-control and management of people's data with hypertension problems in Panama through mobile and biometric devices. The information generated by the device was captured from a blood pressure monitor and stored locally and remotely. This information was linked to the AmIHealth [14] platform, which is used in our country to manage and follow up patients through portable or desktop devices, obtaining medical data from existing biometric devices for the benefit of patients with blood pressure problems. 
There is another research that currently measures various physiological signals like: temperature, heart rate, pulse wave, blood pressure, blood oxygen level, body position, electrocardiograph, body weight, arterial oxygen saturation and electrical activity of the heart can be monitored based on the medical sensors [15]. This prototype also uses mobile communication (i.e. GSM/GPRS) to send alerts and concentrate data on a web server. This server could generate electronic medical records to help doctors in distant locations.

The review of the previous mentioned works allowed us to design our implementation considering aspects that could improve its design, effectiveness and use. Following, we will address the methodology used.

\section{MATERIALS AND METHODS}

For design and development of this system, it is proposed to be used the incremental development methodology; however, first, it is important to define the requirements and materials to be implemented in order to carry out an efficient final product.

\subsection{Materials}

Among the materials for the development of electronic devices we find:

- Arduino One

- XBee Shield

- XBee Adapter

- Raspberry Pi 3 Model B

- $\quad$ Digi XBee S2C module

- Arduino pulse sensor

\subsection{Incremental methodology}

With a project that progressively needs new or deliverable functionalities, the incremental methodology is used. This methodology has the characteristics that these functionalities are developed iteratively and in small work cycles. Furthermore, it consists in increasing a new functionality to the system and checking its effectiveness and that of the system as a whole [16]. Starting with a basic process, then iterating through the incremental model. 


\subsection{Design and development}

For the design and development of this system, efforts are made to work in stages or blocks. Each block will define the various technologies used and their respective function within the entire system. In Figure 1, it is shown the diagram that contains different blocks such as the 6LoWPAN network, the data viewer, the server, and the hybrid gateway. Following is a detailed description of the process: the first section of the system consists of the 6LoWPAN network, in this one are all nodes that send data to the gateway, being these nodes the assistant devices for patients. The data sent by the patient travels from node to node wirelessly using protocol 802.15.4, looking for the nearest node to shorten the route. Once the data reaches the Gateway, consisting of an XBee module, an Arduino and a Raspberry Pi, the data comes from the 6LoWPAN network passes through serial communication to the Raspberry Pi, the data is sent to the dedicated server using the HTTP protocol and stored in the database. Finally, the doctor will be able to observe the information recorded by his patients on the web by accessing the platform and retrieving the files easily.

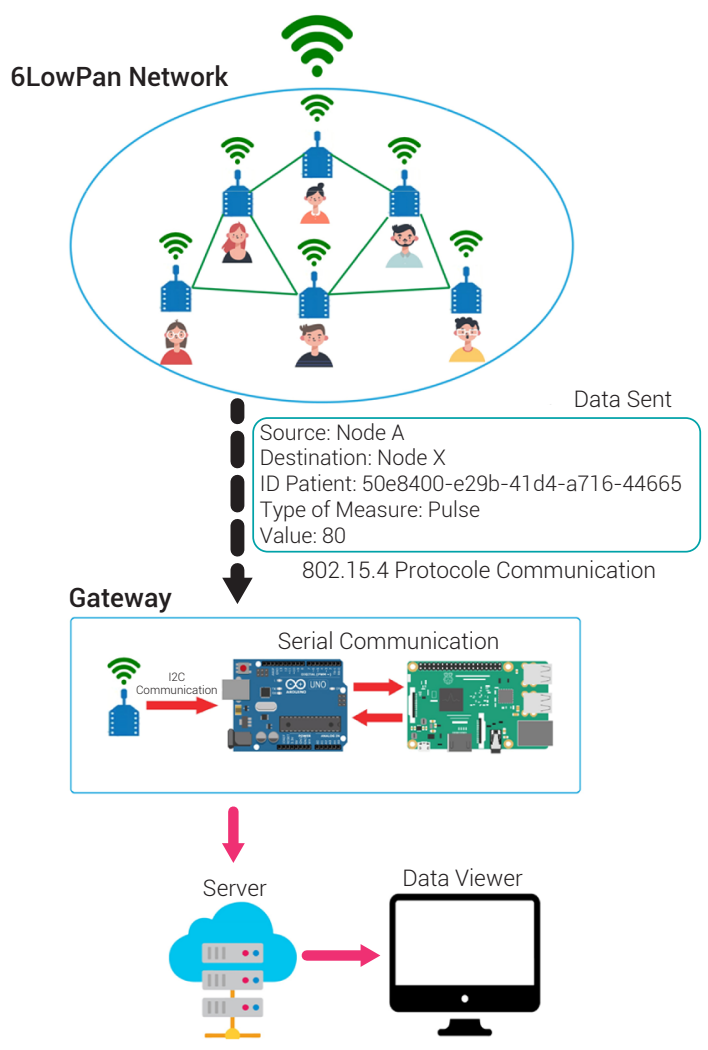

Figure 1. System diagram. Source: own work 
It is important to start with the functional design of the system, for this we build the use case diagram shown in Figure 2. Its definition is based on doctors being able to create users and associate patients in a simple way, and to visualize the data they have recorded from their homes, they need to authenticate with credentials in the system. The following sections detail each of the components in depth.

In figure 2, it can be appreciated who the main actors of the system are: patient and doctors. This has the purpose that the patient will only have the function of entering records on the platform. On the other hand, Doctors will be able to associate the registered patients to their own list and the most important function the doctors will have, is the visualization of the data. As it can be seen, regardless of the role of the doctors, they have to log into the platform.

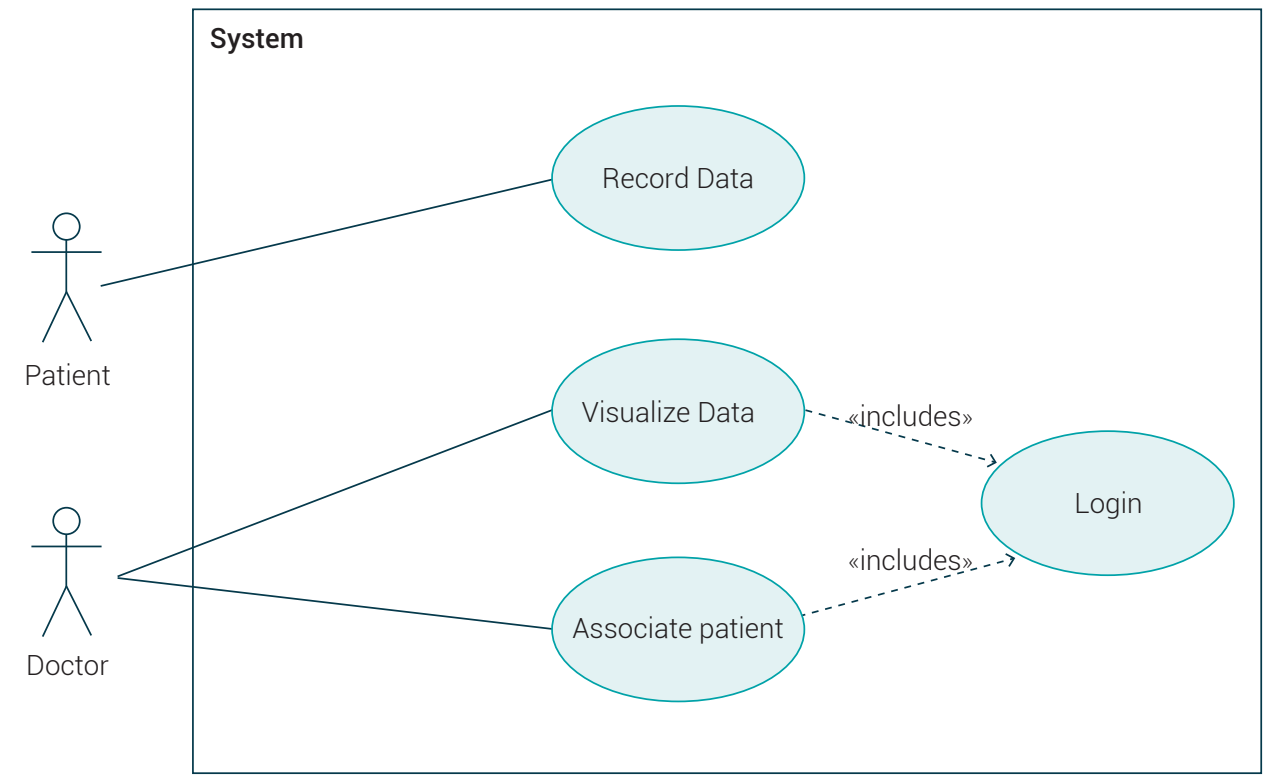

Figure 2. Usage case diagram.

Source: own work

\subsubsection{LOWPAN Network}

A 6LoWPAN network consists of a set of nodes configured in such a way that the messages to be sent to a specific central point (Gateway) are sent in a secure and different way, considering the use of IPV6 [17][18] on each of its nodes. In such networks each node knows its neighboring nodes, this allows the message sent by one node 
to reach its destination by crossing the other nodes as a communication bridge; in this way you have an advantage because, depending on the node power feature, the message has a range limit and when traversing on different nodes as a bridge, the message can reach its destination without data loss. Table 1 shows the comparison of the 6LoWPAN protocol structure with an IP.

Tabla 1. IP and 6LoWPAN protocol stacks over layers of TCP/IP networking model [19]

\begin{tabular}{|c|c|}
\hline \multicolumn{2}{|c|}{ IP Protocol Stacks } \\
\hline \multicolumn{2}{|c|}{ HTTP, SOAP, XMPP } \\
\hline TCP ICMP \\
\hline \multicolumn{2}{|c|}{ IP } \\
\hline \multicolumn{2}{|c|}{ ETHERNET } \\
\hline
\end{tabular}

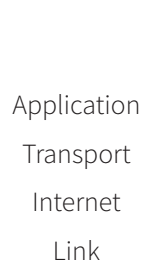

\begin{tabular}{|c|c|}
\hline 6LoWPAN Protocol Stacks \\
\hline COAP, DPWS, XMPP \\
\hline UDP & ICMPV6 \\
\hline \multicolumn{2}{|c|}{ 6LOWPAN Adaptation } \\
\hline \multicolumn{2}{|c|}{ IEEE 802.15.4 } \\
\hline
\end{tabular}

The 6LoWPAN protocol layer introduces an adaptive layer between the data binding layer and the network layer to enable IPv6 frame transmission over technologies such as IEEE 802.15.4. The data binding layer provides a reliable link between two connected nodes by detecting connection failures that can occur at the physical layer during transmission and reception. The internet layer addresses information over the network, even if multiple hops are required. The transport layer generates communication sessions between applications running on devices. This layer allows multiple applications to have their own communication channel. TCP [20] (Transmission Control Protocol) is the dominant transport protocol on the Internet, however, this connection-oriented protocol has too large headers and is therefore not always feasible on low-power devices. For such devices, UDP [21] (User Datagram Protocol) it is a better choice as it is a non-connection-oriented protocol that handles small headers.

Finally, the application layer is responsible for the format of the information. An application layer widely used on the Internet is HTTP (Hypertext Transfer Protocol) over TCP. HTTP uses Extensible Markup Language (XML) which is a text-based language with a large header, so its use on 6LoWPAN networks is not optimal. For this reason, alternative application protocols have been developed, such as CoAP [22] (Constrained Application Protocol), a protocol over UDP that defines relay, confirmed and unconfirmed messages, subscription, and resource discovery.

For the development and deployment of nodes in the network, the XBee S2C module [23] is a used, which is a low-cost module that allows wireless connections between electronic devices, it works with a frequency of $2.4 \mathrm{Ghz}$ and allows 
to create point-to-point, point-to-multipoint, broadcast and mesh connection networks. This module is integrated with el Arduino Uno leaving a node structure as shown in Figure 3.

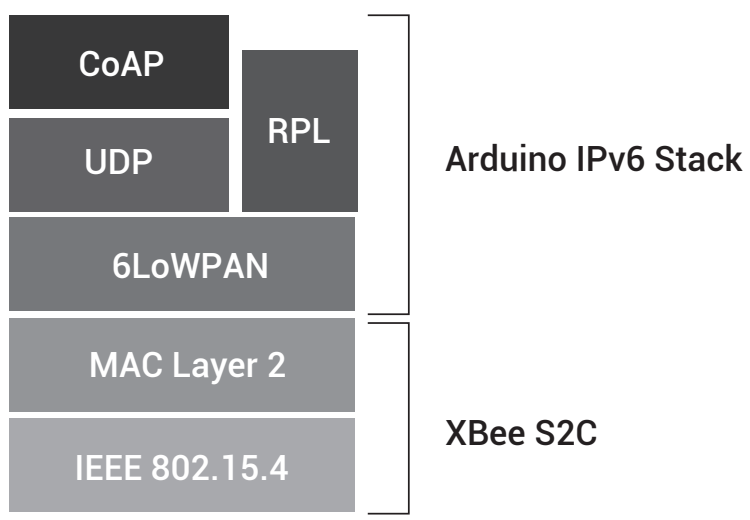

Figure 3. Arduino IPV6 Stack [24]

Nodes as such can play different roles within the network, for ease when configuring their role can be initialized with XCTU software [25], base software for initial configuration of XBee modules and testing. In our case we will configure the patient nodes and the Gateway with Router and Coordinator roles respectively.

\subsubsection{Hybrid Gateway}

The Gateway [26] plays one of the most important roles within the entire system, which is responsible for communicating the 6LoWPAN network with the IP protocol network. In this sense our Gateway will be hybridized, meaning, it will form two parts for its operation. The first consists of an Arduino one and its XBee module as coordinator role representing the 6LoWPAN network and a Raspberry Pi as an IPV6 protocol actor. In this way by connecting the Arduino via serial communication through one of the USB ports of the Raspberry Pi you can send data from one network to another. Once the data is obtained from the Raspberry, it will send the log via HTTP protocol to a dedicated server. Figure 4 shows the final product of the devices on the network. 


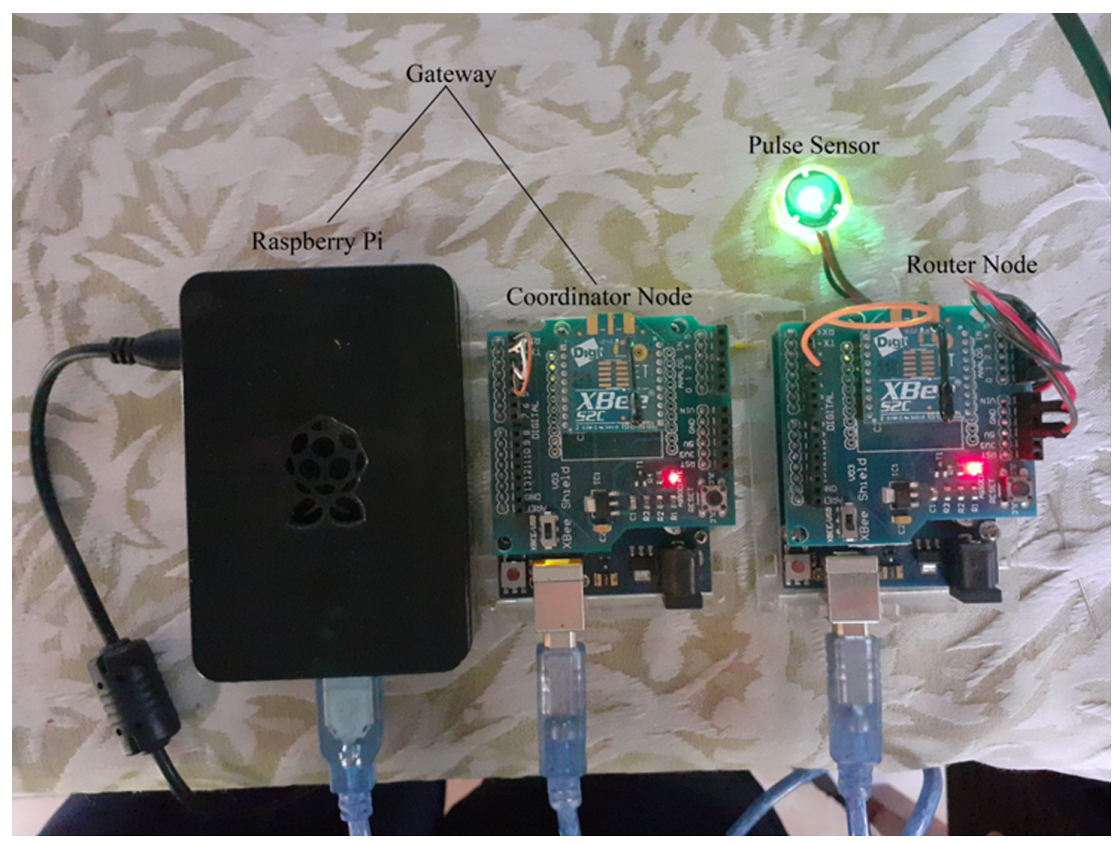

Figure 4. Devices

Source: own work

\subsubsection{Server}

The dedicated server where all patient records will be hosted consists of technologies such as CentOS as an operating system, MariaDB as a database management system, Apache as a server and Laravel as a framework for data management by medical personnel.

\subsubsection{Data viewer}

Finally, for the visualization of patient-created records, doctors will have their respective credentials to access the system and view their patient data. As Laravel is a web framework, doctors will enter through the web the domain created for that system. It is important to emphasize that, in order for a patient to be served and treated through their health records by a specific physician, the physician must create the doctor-patient relationship once they have entered the system.

\subsubsection{Security}

Security in the development environment is essential because when working with delicate and sensitive data, measures are needed to protect the confidentiality, integrity and availability of patient data. 
The 6LoWPAN sensor network establishes a security protocol for encrypting data at the time of being sent from node to node, where only nodes integrated into the network know what type of encryption has been implemented. On the other hand, on the network all data is also encrypted by the web having a unique key that generates the hashes.

\section{RESULTS}

Once you develop the hardware and software the next step that proceeds is to test our design. As part of the descriptive analysis of our assessment, data collection was performed with people of random ages in a range of 18 to 65 years old, in a rural area. This experiment consisted on setting fixed points for pulse measurement, pinpointing the approx. distance with the help of Google Maps and the patient position.

Table 2 shows the data collected from different distances. It should be noted that the XBee module, S2C version, with a maximum range of 60 meters of distance in rural areas from node to node, therefore, the maximum record that could be obtained was 59.01 meters.

It is also important to note that the system is adaptable to record any type of measurement: blood pressure, glucose levels, temperature and so on, making the respective adjustments in the software.

Table 2. Data collected in rural areas

\begin{tabular}{cc}
\hline Distance $(\mathbf{m})$ & Pulse (bpm) \\
\hline 0.53 & 80 \\
\hline 1.09 & 72 \\
\hline 10.53 & 78 \\
\hline 10.53 & 85 \\
\hline 43.31 & 94 \\
\hline 47.27 & 77 \\
\hline 59.01 & 84 \\
\hline 53.63 & 89 \\
\hline 17 & 83 \\
\hline 26.32 & 94 \\
\hline
\end{tabular}

Source: own work

Figures 5, 6 and 7 show the web system views provided to the physician role. Such actors may register and associate their patients (see figure 5), observe the 
measurements of each of their patients sorted by date (see figure 6) and view the entire list of their patients (see figure 7).

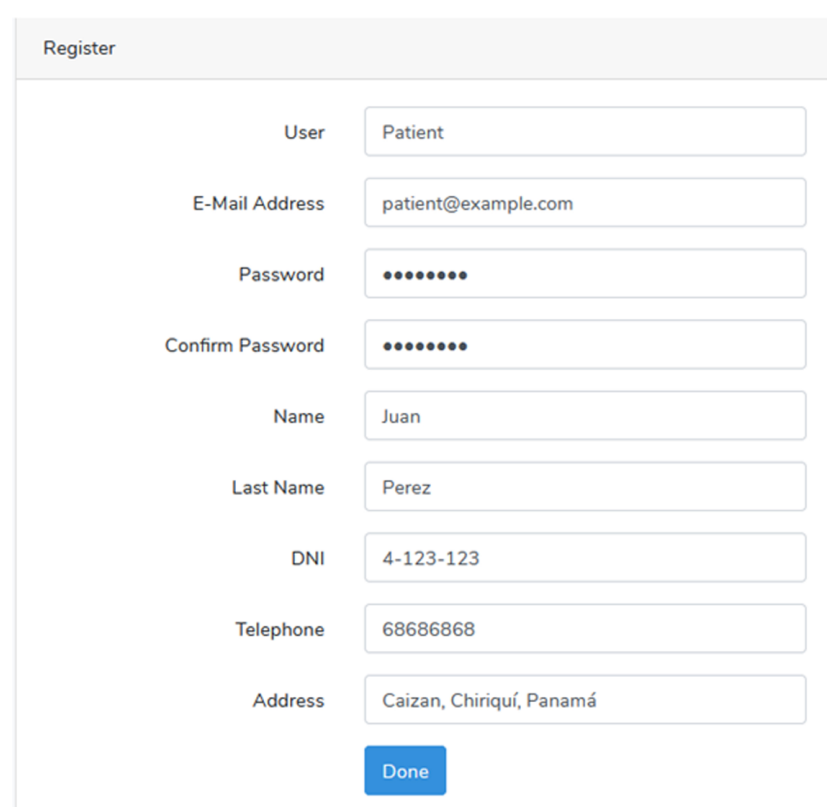

Figure 5. View - Patient registration and association.

Source: own work

\begin{tabular}{|l|l|}
\hline Pulses of amilkar saavedra \\
\hline Measure 1 \\
\hline \begin{tabular}{|l|} 
Pulse: 72 BPM \\
Date: $2019-12-16$ 17:11:45
\end{tabular} \\
\hline Measure 2 \\
\hline Pulse: 89 BPM \\
\hline Date: $2020-03-09$ 18:45:51 \\
\hline Measure 3 \\
\hline Pulse: 72 BPM \\
\hline Date: $2020-03-09$ 18:46:32 \\
\hline Measure 4 \\
\hline Pulse: 93 BPM \\
\hline Date: $2020-03-09$ 18:46:36 \\
\hline Measure 5 \\
\hline Dutse: 75 BPM $2020-03-09$ 18:53:47 \\
\hline
\end{tabular}

Figure 6. View - List of measurements.

Source: own work 
My Patients.

PacienteNombre

Name: PacienteNombre

Last Name: PacienteApellido

DNI: 4-100-456

Telephone: 62520780

Address: Las Lomas

Show measures

amilkar

Name: amilkar

Last Name: saavedra

DNI: 4-123-321

Telephone: 77425785

Address: David

Show measures

Juan

Name: Juan

Last Name: Pérez

DNI: 4-123-123

Telephone: 68686868

Address: Caizan, Chiriquí, Panamá

Show measures

Figure 7. View - Patient list. Source: own work

\section{DISCUSSION}

In the previous points we have presented our design where it could be appreciated that the system is implemented in three parts, hardware, communication and software. Hybrid Gateway represents the main part of the system in order to perform the communication process. Definitely when evaluating the system, we realize that 
a better design can be developed according to the components used, being able to apply improvements in future work implementation. In the software part the patient records could be obtained, since the data is processed and an analysis of the information can be performed immediately, obtaining patient information and their respective records. It is important to note that modifying the XBee module to a higher version could give you greater distances from the point the information is received. An important observation is that at the time the tests were performed, we were able to obtain pulse values, very similar to those taken with a commercial device, which is an indication that the system maintains stable values in its measurements.

Regarding our work: the network architectures presented are very similar to ours, with the difference that they did not consider the security aspects in terms of encryption, neither in the sensor network, nor in the web system.

Due to the limited number of computers for testing, performance could not be checked for data transmission when large numbers of nodes exist, nevertheless, XCTU software has the ability to configure the network for multiple nodes by ensuring functionality when one of the nodes ceases to exist. It should be emphasized that all the measures obtained were in rural areas and due to the COVID-19 situation, it could not be tested in distant areas.

In terms of cost it is easy to implement such a system since all components are inexpensive, being very efficient and scalable, as the software that is used as well, which is Open Source. It is important to point out the cost can be variable depending on the number of nodes in the network.

From the results obtained, we must analyze some important aspects for future work, such as how large 6LoWPAN's coverage can be with other computers and how difficult implementation can be when multiple nodes exist.

\section{CONCLUSIONS}

The implementation of a system like this has great relevance since our country must face the marked inequalities between the urban and rural population, in regard to social determinants and distance, cases of patients who do not have access to regular health services because their residences are in hard access areas. This way, they have better control and recommendations for their illness by their associate doctor.

One of the main advantages of this system is that it is inexpensive, being able to implement in any area without any restriction; however, it could be seen that in rural areas the maximum data transfer distance range was low. It is recommended to select a higher version of the XBee module such as the XBee S2C PRO which has a greater 
range in rural areas and increases the number of nodes around it to cover as much distance as possible.

It is necessary to solve the differences in service coverage and the access to integrated quality health services as well. The technological contributions offered by our proposal would be of significant help.

\section{ACKNOWLEDGMENT}

We want to thank the last author Dr. Vladimir Villarreal, member of National Research System (SNI) for assistance with and for comments that greatly improved the manuscript.

\section{REFERENCES}

[1] T. Torres Fernández, L. Guerra Giménez, A. Ordás González, O. Salas San Juan, and L. M. Sánchez Padilla, "Desarrollo científico y tecnológico. Su impacto en la Atención primaria de salud / Scientific and technological development Its impact on Primary Health Care," Panorama. Cuba y Salud; Volumen 13, Número 3 (36), pp. 91-96, 2018. [Online]. Available: http://revpanorama.sld.cu/index.php/panorama/article/view/834 [Accessed: 01-Jul-2020].

[2] Organización Mundial de la Salud, "Equipos de la OMS asisten a la población en zonas de difícil acceso de Nigeria," https://www.who.int/, 2017. [Online]. Available: https://www.who. int/es/news-room/feature-stories/detail/who-teams-assist-people-in-hard-to-reach-areasof-nigeria [Accessed: 25-Jul-2020].

[3] PAHO, "Access to comprehensive, equitable, and quality health services," Ops/Oms, 2017, pp. 1-10. [Online]. Available: https://www.paho.org/salud-en-las-americas-2017/?p=43 [Accessed: 23-Jul-2020].

[4] Ministerio de Salud, "MINSA prioriza la salud en áreas indígenas y de difícil acceso. Ministerio de Salud de la República de Panamá," 2020-01-08, 2020. [Online]. Available: http://www.minsa.gob.pa/noticia/minsa-prioriza-la-salud-en-areas-indigenas-y-de-dificil-acceso [Accessed: 26-Jul-2020].

[5] N. Kushalnagar, G. Montenegro, and C. Schumacher, "IPv6 over Low-Power Wireless Personal Area Networks (6LoWPANs): Overview, Assumptions, Problem Statement, and Goals," pp. 1-12, 2007. [Online]. doi: 10.17487/rfc4919 
[6] Mukhdeep Singh Manshahia, "Wireless Sensor Network: A Survey," International Journal of Scientific \& Engineering Research, Vol. 7, no. 4, pp. 710-716, 2016. [Online]. Available: https://www.researchgate.net/publication/320385994_Wireless_Sensor_Networks_A_Survey [Accessed: 02-Jun-2020].

[7] IEEE Computer Society, "IEEE Std 802.15.4 ${ }^{\text {TM}}$-2006 (Revision of IEEE Std 802.15.4-2003) Part 15.4: Wireless Medium Access Control (MAC) and Physical Layer (PHY) Specifications for Low-Rate Wireless Personal Area Networks," pp. 13-24, 2006. [Online]. Available: http://www. di.univr.it/documenti/Occorrenzalns/matdid/matdid273763.pdf [Accessed: 26-Jul-2020].

[8] W. R. Ruiz Sánchez, "Redes de sensores inalámbricos enfocadas a la medicina con énfasis en control de los signos vitales en pacientes adultos mayores," Pontificia Universidad Católica del Ecuador PUCE, pp. 29-40, 2016. [Online]. Available: http://repositorio.puce.edu.ec/handle/22000/11311 [Accessed: 20-Jun-2020].

[9] The Apache Software Foundation, "NetBeans," 2020. [Online]. Available: www.netbeans.org [Accessed: 12-Jul-2020].

[10] J. M. Alarcón López, Álvaro Hernán; Arias Vargas, Geyni; Llanos Mosquera, "Sistema de medición de temperatura corporal a través de dispositivos móviles para monitorear niveles de fiebre en niños entre los 0 y 5 años en la ciudad de Neiva Body temperature measurement system through mobile devices to monitor fever levels in children," Memorias Congr. UTP, vol. 1, no. September, pp. 21-27, 2018.

[11] Y. R. Baque Quimis and K. F. Tomala Cantos, "Prototipo de una red de sensores inalámbricos para el monitoreo de hipertensión con pacientes en estado de gestación," Universidad de Guayaquil, pp. 3-10, 2018. [Online]. Available: http://repositorio.ug.edu.ec/handle/redug/33824. [Accessed: 15-Jun-2020].

[12] R. Yauri Rodríguez, "Implementación de una Red inalámbrica de sensores para el monitoreo remoto de variables fisiológicas en pacientes ambulatorios," Universidad Nacional del Callao, pp. 11-20, 2018. [Online]. Available: http://repositorio.unac.edu.pe/handle/UNAC/2816.

[13] V. Villarreal Contreras and M. I. Nielsen Pimentel, "Implementación de una aplicación móvil para facilitar el autocontrol de la hipertensión en Panamá," Ing. Solidar., vol. 14, no. 24, pp. 1-12, 2018. [Online]. doi: 10.16925/in.v14i24.2156

[14] M. Samudio y V. Villarreal, "AmIHEALTH: Plataforma web para el seguimiento y control de pacientes con problemas de hipertensión arterial en Panamá," in Memorias De Congresos UTP, 2017, pp. 28-34. 
[15] G. P. Guano, D. Alulema, and E. V. Carrera, "A portable electronic system for health monitoring of elderly people," in IEEE Colombian Conference on Communications and Computing, COLCOM 2015 - Conference Proceedings, pp. 1-6, 2015. [Online]. doi: 10.1109/ COLCOMCON.2015.7152091

[16] OBS Bussiness School, "Características y fases del modelo incremental," 2020. [Online]. Available: https://obsbusiness.school/int/blog-project-management/metodologias-agiles/ caracteristicas-y-fases-del-modelo-incremental. [Accessed: 28-Jul-2020].

[17] S. Deering and R. Hinden, "Internet Protocol, Version 6 (IPv6) Specification, pp. 4-11, 2017. [Online]. doi: 10.17487/RFC8200

[18] I. P. S. Benítez, G. A. Méndez, N. M. A. Salazar, D. C. Burbano, and C. I. U. Guirales, "Análisis comparativo de los Protocolos IPV6 e IPV4," Ingeniería Solidaria, pp. 1-12, 2010. [Online]. Available: https://revistas.ucc.edu.co/index.php/in/article/view/465

[19] S. N. Han, Q. H. Cao, B. Alinia, and N. Crespi, "Design, implementation, and evaluation of 6LoWPAN for home and building automation in the Internet of Things," in Proceedings of IEEE/ ACS $12^{\text {th }}$ International Conference of Computer Systems and Applications, AICCSA, 2015, pp. 1-8. [Online]. doi: 10.1109/AICCSA.2015.7507264

[20] J. Postel, "Transmission control protocol specification," Requestfor Comments, 1981, pp. 7-15. [Online]. doi: 10.17487/rfc0793

[21] J. Postel, "RFC 768 User Datagram Protocol - DARPA Internet Program, Protocol Specification," 1980, pp. 1-3. [Online]. doi: 10.17487/RFC0768

[22] Z. Shelby, K. Hartke, and C. Bormann, "The Constrained Application Protocol (CoAP)," Jun. 2014, pp. 10-20. [Online]. doi: 10.17487/RFC7252

[23] XBEE.cl, "XBee ZB S2C TH - Comunicación Inalámbrica para Tus Proyectos," 2020. [Online]. Available: http://xbee.cl/xbee-zb-s2c-th/. [Accessed: 23-Aug-2020].

[24] C. Lazo, P. Gallardo and S. Céspedes, "A bridge structural health monitoring system supported by the Internet of Things," IEEE Colombian Conference on Communication and Computing, COLCOM 2015 - Conference Proceedings, 2015, pp. 1-6. [Online]. doi: 10.1109/ ColComCon.2015.7152094

[25] Digi.com, "XCTU," 2020. [Online]. Available: www.digi.com/products/embedded-systems/digi-xbee/digi-xbee-tools/xctu. [Accessed: 02-Aug-2020]. 
[26] A. Garcia, "Estudio y desarrollo de un equipo interfaz de red inalámbrica (WSN) con red pública basado en plataforma Raspberry Pi," Universidad Politécnica de Valencia, pp. 12-18, 2016. [Online]. Available: http://hdl.handle.net/10251/74271 